\section{The possible role of mutated endothelial cells in myeloproliferative neoplasms}

\author{
Mirko Farina, ${ }^{1}$ Domenico Russo ${ }^{1}$ and Ronald Hoffman ${ }^{2}$ \\ ${ }^{1}$ Unit of Blood Diseases and Bone Marrow Transplantation, Cell Therapies and Hematology \\ Research Program, Department of Clinical and Experimental Sciences, University of \\ Brescia, ASST Spedali Civili di Brescia, Brescia, Italy and ${ }^{2}$ Division of Hematology and \\ Medical Oncology, Tisch Cancer Institute, Icahn School of Medicine at Mount Sinai, New \\ York, NY, USA
}

\section{ABSTRACT}

M yeloproliferative neoplasms (MPN) are chronic, clonal hematologic malignancies characterized by myeloproliferation and a high incidence of vascular complications (thrombotic and bleeding). Although MPN-specific driver mutations have been identified, the underlying events that culminate in these clinical manifestations require further clarification. We reviewed the numerous studies performed during the last decade identifying endothelial cell (EC) dysregulation as a factor contributing to MPN disease development. The JAK2V617F MPN mutation and other myeloid-associated mutations have been detected not only in hematopoietic cells but also in EC and their precursors in MPN patients, suggesting a link between mutated EC and the high incidence of vascular events. To date, however, the role of $\mathrm{EC}$ in MPN continues to be questioned by some investigators. In order to further clarify the role of EC in MPN, we first describe the experimental strategies used to study EC biology and then analyze the available evidence generated using these assays which implicate mutated EC in MPN-associated abnormalities. Mutated EC have been reported to possess a pro-adhesive phenotype as a result of increased endothelial Pselectin exposure, secondary to degranulation of Weibel-Palade bodies, which is further accentuated by exposure to pro-inflammatory cytokines. Additional evidence indicates that MPN myeloproliferation requires $J A K 2 \mathrm{~V} 617 \mathrm{~F}$ expression by both hematopoietic stem cells and EC. Furthermore, the reports of JAK2V617F and other myeloid malignancy-associated mutations in both hematopoietic cells and EC in MPN patients support the hypothesis that MPN driver mutations may first appear in a common precursor cell for both EC and hematopoietic cells.

\section{Introduction}

The Philadelphia chromosome-negative myeloproliferative neoplasms (MPN) include polycythemia vera, essential thrombocythemia and primary myelofibrosis. ${ }^{1}$ These clonal hematopoietic stem cell (HSC) disorders are characterized by an increased rate of vascular complications including thrombotic and bleeding episodes. ${ }^{2,3}$ However, the mechanisms underlying these vascular events remains uncertain and have been the subject of considerable speculation and debate for decades. ${ }^{4,5}$ Recently, new insights into factors contributing to the development of thrombotic events in MPN patients have become available, ${ }^{6}$ including the role of endothelial cells (EC) that contain MPN driver mutations. Physiologically, EC participate in the maintenance of vascular integrity, and generate an anti-thrombotic surface. ${ }^{7}$ During the last decade, the JAK2V617F MPN driver mutation has been shown to be present in $\mathrm{EC}^{8,9}$ and their progenitors ${ }^{10-12}$ in some MPN patients, suggesting a link between mutated EC and the high incidence of vascular events. This concept and its implications remain controversial and its significance has been questioned by some investigators. ${ }^{9,11,13}$ The aim of this review is to analyze this evidence in a critical fashion and assess the validity of the link between EC and MPN pathobiology.
Ferrata Storti Foundation

Haematologica 2021

Volume 106(11):2813-2823

\section{Correspondence: \\ MIRKO FARINA \\ mirkfar@gmail.com}

Received: February 17, 2021.

Accepted: June 28, 2021.

Pre-published: July 29, 2021.

https://doi.org/10.3324/haematol.2021.278499

(C)2021 Ferrata Storti Foundation

Material published in Haematologica is covered by copyright. All rights are reserved to the Ferrata Storti Foundation. Use of published material is allowed under the following terms and conditions:

https://creativecommons.org/licenses/by-nc/4.0/legalcode. Copies of published material are allowed for personal or internal use. Sharing published material for non-commercial purposes is subject to the following conditions:

https://creativecommons.org/licenses/by-nc/4.0/legalcode, sect. 3. Reproducing and sharing published material for commercial purposes is not allowed without permission in writing from the publisher. 


\section{Myeloproliferative neoplasms and vascular complications}

Vascular complications are the most common clinical sequelae and a major cause of morbidity and mortality in MPN patients. ${ }^{2,3}$ The incidence and the characteristic clinical presentations of vascular events in MPN patients are summarized in Table 1.

Thrombotic events are often the initial manifestation of an MPN or may precede the diagnosis of the MPN. Thrombosis appears to be more common among patients with polycythemia vera than in those with essential thrombocythemia or primary myelofibrosis both at diagnosis ${ }^{3}$ and during follow up ${ }^{2}$ (Table 1). Bleeding episodes are less frequent than thrombotic events in MPN patients; and, contrary to thrombosis, occur primarily after the diagnosis of the MPN has been established ${ }^{14}$ (Table 1$)$.

\section{Factors predisposing to thrombosis in patients with myeloproliferative neoplasms}

Many features of a patient's demographics are predictive of MPN-associated thrombotic complications ${ }^{15-17}$ including age, prior thrombotic events, an inflammatory state, and MPN-associated risk factors, such as degree of erythrocytosis, leukocytosis, and the presence of JAK2V617F. By contrast, individuals with calreticulin mutations have a lower risk of thrombosis than those with JAK2V617F. ${ }^{2}$ Notably, the frequency of the JAK2V617F variant allele influences the degree of thrombotic risk ${ }^{18}$ in patients with essential thrombocythemia, while contradictory results were found in patients with polycythemia vera. Conventional cardiovascular risk factor (e.g., hypertension, hyperlipidemia, diabetes and smoking) are additional variables associated with an increased rate of thrombosis. Among factors predisposing to thrombosis, only age greater than 60 years and a prior history of a thrombotic event were validated as thrombotic risk factors in MPN patients, while conflicting results have been reported for other proposed predisposing factors. ${ }^{2,15,16}$ However, the presence of JAK2V617F as an MPN driver mutation has been confirmed as a predictor of additional thrombotic events in patients with essential thrombocythemia. ${ }^{15,16}$

The history of thrombotic events prior to a diagnosis of MPN may also be attributed to the presence in these patients of a clonal hematopoiesis of indeterminate potential (CHIP), involving JAK2V617F or calreticulin mutations prior to the development of a full blown MPN. Indeed, CHIP has been associated with an increased risk of coronary artery disease and stroke..$^{19}$ In particular, JAK2V617F CHIP has been most frequently associated with an increased risk of developing cardiovascular diseases, thrombosis and coronary heart disease. ${ }^{19}$ Furthermore, Cordua et al..$^{20}$ have shown that subjects with JAK2V617F or calreticulin CHIP frequently eventually develop a full-blown MPN.

The underlying events that lead to thromboses in MPN patients remain the subject of investigation. Historically, the thrombotic tendency may be influenced, as outlined

Table 1. Incidence and main clinical characteristics of vascular events in patients with myeloproliferative neoplasms.

\begin{tabular}{|c|c|c|c|c|c|c|c|c|c|}
\hline \multirow[b]{2}{*}{ Disease } & \multirow[b]{2}{*}{$\begin{array}{l}\text { Molecular } \\
\text { features }\end{array}$} & \multirow[b]{2}{*}{$\begin{array}{l}\text { Main } \\
\text { Phenotype }\end{array}$} & \multicolumn{4}{|c|}{ THROMBOSIS } & \multicolumn{3}{|c|}{ BLEEDINGS } \\
\hline & & & Incidence & Type & $\begin{array}{l}\text { Clinical } \\
\text { characteristics }\end{array}$ & Ref. & Incidence & $\begin{array}{l}\text { Clinical } \\
\text { characteristics }\end{array}$ & Ref. \\
\hline PV & $\begin{array}{l}J A K 2 \text { V617F (95\%) } \\
J A K 2 \text { exon } 12(5 \%) \\
\text { Sub-clonal } \\
\text { mutations in } \\
\text { myeloid genes }\end{array}$ & $\begin{array}{l}\text { Erythrocytosis. } \\
\text { which can be } \\
\text { associated with } \\
\text { leukocytosis and } \\
\text { thrombocytosis. }\end{array}$ & $\begin{array}{l}\text { - At diagnosis: } 28.6 \% \\
\text { - During follow up: } \\
3.8 \text { x } 100 \text { person/year } \\
\text { (1.5 deaths per } \\
100 \text { person/year) }\end{array}$ & $\begin{array}{l}\text { Both } \\
\text { arterial } \\
\text { and } \\
\text { venous }\end{array}$ & $\begin{array}{l}\frac{\text { Mild }}{\text { microcirculatory }} \\
\frac{\text { disturbances }}{\text { (headache, }} \\
\text { itching, buzzing) }\end{array}$ & $2,3,17$ & $\begin{array}{l}\text { 3-8\% (usually } \\
\text { after the } \\
\text { diagnosis) }\end{array}$ & $\begin{array}{l}\text { - Minor bleeding } \\
\text { (e.g. ecchymoses, } \\
\text { gingival hemorrhage, } \\
\text { menorrhagia and } \\
\text { epistaxis) }\end{array}$ & 14 \\
\hline ET & $\begin{array}{l}\text { JAK2 V617F (60\%) } \\
\text { MPL exon } 10(5 \%) \\
\text { CALR exon } 9(20 \%) \\
\text { Triple negative } \\
\text { (5-10\%) } \\
\text { Sub-clonal mutations } \\
\text { in myeloid genes }\end{array}$ & $\begin{array}{l}\text { Thrombocytosis. } \\
\text { Sometimes } \\
\text { patients presented } \\
\text { with normal white } \\
\text { blood cell counts. } \\
\text { A reduced red } \\
\text { blood cell count } \\
\text { can also be } \\
\text { observed }\end{array}$ & $\begin{array}{l}\text { - At diagnosis: } 20.7 \% \\
\text { - During follow up: } \\
\text { 2-4 x } 100 \text { person/year }\end{array}$ & $\begin{array}{c}\text { Mainly } \\
\text { arterial }\end{array}$ & $\begin{array}{l}\frac{\text { Major arterial }}{\text { and venous }} \\
\frac{\text { thrombotic events }}{\text { (ischemic stroke, }} \\
\text { peripheral artery } \\
\text { disease, splanchnic } \\
\text { vein thromboses, } \\
\text { cerebral sinus } \\
\text { thromboses, myocardial } \\
\text { infarction, and deep } \\
\text { vein thromboses) }\end{array}$ & $2,3,17,22$ & $\begin{array}{l}3 \text { - } 18 \% \text { (usually } \\
\text { after the } \\
\text { diagnosis) }\end{array}$ & $\begin{array}{l}\text { - Major bleeding } \\
\text { (e.g. intracranial } \\
\text { hemorrhage, } \\
\text { gastrointestinal } \\
\text { bleeding, } \\
\text { retroperitoneal bleeding) } \\
\text { - Extreme thrombocytosis } \\
\text { may cause bleeding } \\
\text { due to development of an } \\
\text { acquired Von Willebrand } \\
\text { syndrome }\end{array}$ & 14,29 \\
\hline $\mathrm{MF}$ & $\begin{array}{l}\text { JAK2 V617F (60\%) } \\
\text { MPL exon } 10(5 \%) \\
\text { CALR exon } 9(20 \%) \\
\text { Triple negative } \\
(5-10 \%) \\
\text { Sub-clonal mutations } \\
\text { in myeloid genes. } \\
\text { (ASXL1, DMT3A, } \\
\text { EZH2, IDH1/IDH2, } \\
\text { SRSF2, or TP53 are } \\
\text { associated with } \\
\text { a worse outcome) }\end{array}$ & $\begin{array}{l}\text { Splenomegaly } \\
\text { (85\%); Cytopenia: } \\
\text { - 2/3 of patients } \\
\text { had anemia } \\
\text { at diagnosis; } \\
\text { - } 40 \text { to } 50 \% \text { have } \\
\text { leukocytosis } \\
\text { - 13-32\% have } \\
\text { thrombocytosis }\end{array}$ & $\begin{array}{l}\text { - At diagnosis: } 9.5 \% \\
\text { - During follow up: } \\
2.2 \text { x } 100 \text { person/year }\end{array}$ & $\begin{array}{l}\text { Both } \\
\text { arterial } \\
\text { and } \\
\text { venous }\end{array}$ & $\begin{array}{l}\text { Over-representation } \\
\text { of thrombosis in unusua } \\
\underline{\text { sites (portal system, }} \\
\text { Budd-Chiari syndrome, } \\
\text { cerebral venous } \\
\text { thrombosis) }\end{array}$ & $\begin{array}{l}2,3,4,5 \\
\text { al }\end{array}$ & $\begin{array}{l}19-56 \% \\
(\sim 12 \% \text { in } \\
\text { patients with } \\
\text { pre-fibrotic } \\
\text { myelofibrosis })\end{array}$ & $\begin{array}{l}\text { - Main cause of bleedings } \\
\text { are Portal hypertension } \\
\text { with esophageal varices, } \\
\text { the use of anti-platelet } \\
\text { and/or anti-coagulant } \\
\text { therapy }\end{array}$ & $4,14,29$ \\
\hline
\end{tabular}

PV: polycythemia; ET: essential thrombocythemia; MF: myelofibrosis; ref.: references. 
below, by a combination of increased numbers of abnormal myeloid cells and the co-existence of a chronic inflammatory state. ${ }^{2}$ Recently, new evidence has shown a role for endothelial cells, which is the subject of this review.

\section{Blood cell alterations and thrombotic tendency in myelo- proliferative neoplasms}

The elevated number of red cells and the resultant increased hematocrit levels are well established to have pro-thrombotic effects. ${ }^{2}$ Under low shear rates an elevated hematocrit leads to increased blood viscosity, while at high shear rates, the increased red cell numbers disperse platelets toward the vessel walls, resulting in platelet activation. Finally, biochemical changes have been observed in red cell membranes both in patients with polycythemia vera and in those with essential thrombocythemia, causing red blood cell aggregation. ${ }^{2}$ In contrast to red blood cells, there are few studies on platelets directly correlating the degree of thrombocytosis with the rate of thrombosis in MPN patients. ${ }^{21}$ The impact of leukocytosis on thrombosis has been evaluated in numerous retrospective studies, but with discordant results. Several studies suggest that the adhesion of leukocytes to EC contributes to the development of thrombosis, especially the formation of venous thrombi. ${ }^{22}$ By contrast, it has been recently documented that persistent leukocytosis in polycythemia vera was associated with disease progression, rather than thrombosis. ${ }^{23}$ In general, neutrophils play a central role in generating the inflammatory response and in activation of the blood coagulation system through the release of proteolytic enzymes and reactive oxygen species and the increased expression of CD11b which activates or damages platelets, EC and coagulation proteins. ${ }^{2}$ Moreover, granulocytes in MPN patients produced an increased amount of neutrophil extracellular traps that initiate and propagate arterial and venous thrombosis..$^{24,25}$ Mouse models have demonstrated that neutrophil extracellular traps are crucial in the development of thrombosis. ${ }^{32}$

Moreover, MPN blood cells are also qualitatively abnormal due to their procoagulant and proteolytic properties, secretion of inflammatory cytokines, and expression of cell adhesion molecules. ${ }^{2}$ In particular, activated platelets in MPN patients express P-selectin and tissue factor and secrete an increased number of platelet activation products. $^{26}$

\section{Inflammation and thrombosis}

In concert, inflammatory cytokines secreted by MPN cells and leukocyte-derived proteases damage the integrity of the normal vascular endothelium, leading to the acquisition of a pro-thrombotic phenotype in MPN patients. Specifically, EC overexpress adhesion receptors favoring the attachment of platelets, erythrocytes, and leukocytes to the vascular wall. In addition, MPN patients have increased levels of circulating procoagulant microparticles which are associated with activation of protein $\mathrm{C}^{2}{ }^{2}$

\section{Endothelial cells and thrombosis}

In general, numerous insults occur in MPN patients, which perturb the integrity of the endothelium, resulting in a pro-adhesive and pro-coagulant EC surface. Over the last decade, increasing evidence has been provided indicating that JAK2-mutated MPN EC might also contribute to the MPN pro-thrombotic state..$^{27,28}$ This evidence will be reviewed here.

\section{Bleeding risk factors in patients with myeloproliferative neoplasms}

Risk factors for developing hemorrhagic events are less well understood. The JAK2V617F mutation has not only been related to the rate of thrombosis, but also to the rate of bleeding events. ${ }^{4}$ Furthermore, thrombocytopenia due to hypersplenism and/or progressive myelofibrosis may enhance the risk of bleeding. ${ }^{14}$ Paradoxically, extreme thrombocytosis is associated with bleeding due to the development of acquired von Willebrand syndrome. ${ }^{21}$ The type of MPN also appears to influence the hemorrhagic risk, with an increased incidence being associated with prefibrotic primary myelofibrosis as compared to essential thrombocythemia. ${ }^{29}$ In general, the effect of the administration of antiplatelet aggregating agents on bleeding events in MPN patients is debatable. These agents should however be used with caution in patients with extreme thrombocytosis and acquired von Willebrand syndrome, severe thrombocytopenia, or in those receiving oral anticoagulants.

There are several possible factors that contribute to bleeding in MPN patients, including both disease-related factors (e.g., MPN subtypes, thrombocytopenia or extreme thrombocytosis, platelet storage pool defects with a downregulation of glycoproteins (GP)Ib and GPIIb/IIIa and therapy-related factors (e.g., use of antiplatelet and anticoagulant therapies, ${ }^{27}$ drug-induced thrombocytopenia due to ruxolitinib, fedratinib, interferon, busulfan or hydroxyurea).

\section{Endothelial cell involvement in myeloprolifera- tive neoplasms}

A significant increase in marrow and splenic microvascular density ${ }^{30}$ is a characteristic feature of MPN, particularly polycythemia vera and myelofibrosis. Moreover, neo-angiogenesis represents a hallmark of these diseases. $^{31}$ Whether neo-angiogenesis in MPN is an epiphenomenon of the MPN pro-inflammatory milieu or a consequence of EC dysregulation due to the same pathogenic mechanism that leads to the hematopoietic cell proliferation $^{32}$ remains controversial. It is important to realize that these two mechanisms are not mutually exclusive and could be operating in concert. In addition, increased serum levels of pro-angiogenic factors, such as vascular endothelial growth factor (VEGF), have been reported in MPN patients. ${ }^{33}$ It has been suggested that autocrine and paracrine signaling pathways lead to increased levels of VEGF, which may not only contribute to accelerated hematopoietic cell growth but may also contribute to the MPN-associated risk of thrombosis. ${ }^{34}$

The increased marrow and splenic microvessel density and neo-angiogenesis, together with the high incidence of vascular complications, has led some authors to hypothesize direct involvement of EC by the malignant process in $\mathrm{MPN}$. The observation that EC and their precursors may harbor the JAK2V617F mutation supports this hypothesis. ${ }^{8,9,12,39,42,43}$ However, studying the contribution of EC to human disease development is challenging because endothelium cannot, for ethical reasons, be easily sampled from patients. This limitation has meant that most published papers providing support for the abovementioned hypothesis are based on in vitro studies dealing with circulating endothelial progenitors, ${ }^{32,34,37}$ and mature 
EC. ${ }^{8,9}$ Moreover, some authors demonstrated that monocytes isolated from MPN patients are capable of generating cells that closely resemble EC, the so-called endothelial-like cells or angiogenic monocytes. ${ }^{38}$ Both in animal models and humans, angiogenic monocytes contribute to neo-vessel formation while assuming a mature EC phenotype..$^{38}$ However, in humans it is currently thought that endothelial-like cells influence angiogenesis by secreting pro-angiogenic factors (paracrine effects), rather than participating directly in neovascularization. ${ }^{39}$

At present, the true origin of mutated EC in MPN patients remains the subject of debate. Where do these cells originate from? Can we be certain of their true EC nature? In the following sections we review the instruments that are presently used to study EC biology in order for the reader to better appreciate the challenges encountered in understanding the origins and consequences of JAK2-mutated EC.

\section{Assays for endothelial cells and endothelial progenitor cells}

A growing number of assays have been utilized to study the origins of EC in MPN. It is impossible to evaluate the validity of such data without first understanding the nature of each of these assays as well as their strengths and limitations. We will describe each of the currently used assays below.

Circulating endothelial progenitor cells (EPC) (Table 2) have the capacity to proliferate, migrate, and differentiate into cells belonging to the endothelial lineage, but do not acquire the characteristic features of mature EC. EPC are very rare peripheral blood cells $(0.0001 \%$ of circulating nucleated cells).$^{40}$ In both animal models and humans they have been reported to play a role in vascular repair and neo-angiogenesis..$^{40}$ Asahara et al. ${ }^{40}$ initially reported the isolation of a putative EPC from human peripheral blood, on the basis of cell surface expression of CD34 (expressed by EC, as well as HSC) and Flk-1 (a receptor for VEGF2). These cells were capable of de novo blood vessel tube formation. Subsequently, Urbich and Dimmeler ${ }^{41}$ defined EPC as progenitors of EC that were capable of clonal expansion with stem cell-like characteristics and had the capacity to differentiate into EC. Since these initial observations, there has been a great deal of debate concerning the definition and characterization of these progenitor cells. In addition, a variety of methods have been used to detect and characterize EPC, which has led to disparate results. ${ }^{49}$ Three main approaches have been used to identify and isolate EPC.

One approach is to identify EPC using surface antigen expression with cytofluorimetry of circulating cells (Table 3). Unfortunately, the presently used cell surface markers, CD34, VEGFR2 (human KDR and mouse Flk-1) and CD133 do not unequivocally identify EPC. ${ }^{37}$ This approach allows EPC to be distinguished from mature circulating endothelial cells (CEC), since CD133 is a stem cell marker expressed by EPC but not by mature EC. ${ }^{43}$

A second method of assaying for EPC consists of plating human peripheral blood or cord blood low-density mononuclear cells in culture dishes coated with fibronectin in a commercially available culture medium rich in EC growth factors and fetal calf serum. ${ }^{44}$ After 4-5 days the non-adherent cells are removed and the adherent cells are examined for their ability to bind acetylated low-density lipoprotein and Ulex europaeus agglutinin 1 (a plant lectin). The putative EPC identified are called circulating angiogenic cells. These markers, however, lack specificity $^{45}$ (numerous blood cells express the integrin receptors for fibronectin) and these cells typically do not form EC colonies in vitro. ${ }^{46}$ EPC identified in this manner are thought to contribute to neo-angiogenesis by secreting angiogenic factors (paracrine route). ${ }^{46}$

The third method to quantitate the numbers of EPC is based on the in vitro colony-forming capacity of cultured $\mathrm{CD}_{3}{ }^{+}$cells. Two classes of EPC have been described, which are termed colony-forming unit-endothelial cells (CFU-EC) and endothelial colony-forming cells (ECFC). CFU-EC are assayed by plating $\mathrm{CD} 4^{+}$cells for $48 \mathrm{~h}$ in fibronectin-coated dishes and then replating the nonadherent cells and monitoring for the emergence of the EPC-derived colonies. These CFU-EC, however, fail to display any postnatal vasculogenic activity and are thought ultimately to be the cellular progeny of myeloid cells. ${ }^{45}$ Since this assay includes the adhesion of mononu-

Table 2. Main abbreviations referring to endothelial progenitor cells and mature endothelial cells, and brief definitions of the types of cells.

Abbreviation Definition

$\mathrm{EPC}=$ endothelial progenitor cell

Endothelial progenitors that differentiate into endothelial cells and may become part of the newly formed vessel wall or favor angiogenesis by secretion of pro-angiogenic factors (paracrine effect). There are several ex vivo assays for EPC.

$\mathrm{ECFC}=$ endothelial colony-forming cells Among the EPC, ECFC originate from peripheral blood mononuclear cells and are able to form large colonies of human CD45- cells after 1-3 weeks of incubation (once called late outgrowth endothelial cells, OEC), which have phenotypic and functional properties of endothelial cells. Indeed, they are able to generate new vessels in vivo and to generate endothelial colonies ex vivo, and are now considered the true precursor cells of endothelial cells.

CFU-EC = colony-forming unit-endothelial These are assayed by plating CD $34^{+}$cells for $48 \mathrm{~h}$ in fibronectin-coated dishes and then replating the cells non-adherent cells and monitoring for the emergence of the EPC-derived colonies. Because of the brief period of incubation ex vivo they were once called early outgrowth endothelial cells, (EOC). They were initially included as endothelial precursors, but they do not possess any postnatal vasculogenic activity and, therefore, are no longer considered true EPC.

$\mathrm{CAC}=$ circulating angiogenic cells Bone marrow-derived immune cell populations (T cells and certain subsets of monocytes) that stimulate vascular regeneration and angiogenesis through a paracrine mechanism.

$\mathrm{CEC}=$ circulating endothelial cells Mature endothelial cells circulating in the peripheral blood, which are shed from vessel walls as a result of pathophysiological conditions that affect the endothelium.

$\mathrm{ELC}=$ endothelial-like cells Monocytes that closely resemble endothelial cells and acquire endothelial cell surface markers. 
clear cells in vitro, this approach may select for monocytes, expressing "endothelial-specific" markers. ${ }^{38}$

Another assay system identifies outgrowth EC. This assay identifies clonal ECFC capacity of EPC, which form large colonies of human CD45- cells after 1-3 weeks of incubation. ${ }^{45}$ The cells within these colonies are thought to be of EC origin because of their: EC morphology, expression of EPC/EC-related markers (CD31, CD105, CD144, CD146, VWF, and KDR) ${ }^{36}$ and spontaneous formation of human blood vessel tubes in vitro ${ }^{47}$ and in vivo (postnatal vasculogenesis). ${ }^{48}$ The ability of ECFC to display spontaneous vasculogenic properties and to remodel into arteries and veins in vivo distinguishes ECFC from all other EC precursor or progenitor cell types previously described. ${ }^{45}$ ECFC are likely the cell population that represents a true lineage-restricted EC progenitor cell.

\section{Circulating endothelial cells}

CEC are mature differentiated EC that are shed from vessel walls as a result of pathophysiological conditions that affect the endothelium. ${ }^{49} \mathrm{CEC}$ were first identified in the 1970s although more user-friendly techniques to isolate CEC have only recently become available..$^{50}$ Prolonged or exaggerated activation by environmental stress leads to dysfunction and to irreversible loss of EC integrity with cell detachment, apoptosis and necrosis, which results in greater EC turnover and increased CEC levels in peripheral blood. ${ }^{50}$

CEC were initially identified using morphological criteria. Subsequently, objective methods to identify CEC with the application of immunofluorescence, and the use of antibodies against various EC markers, were introduced although these efforts have been hampered by the lack of reliable cell-specific markers. ${ }^{51}$ Recently a consensus definition of CEC has been reached, ${ }^{52}$ according to which CEC are large (>10 $\mu \mathrm{m}$ in length) $\mathrm{CD}_{146^{+}}$cells. CD146 (MUC18) is expressed by CEC but not by monocytes, granulocytes, platelets, megakaryocytes, $\mathrm{T}$ or B lympho-

Table 3. Biological characteristics and immunophenotype of endothelial progenitor cells and circulating endothelial cells.

\begin{tabular}{|c|c|c|c|c|}
\hline & CAC & $\begin{array}{l}\text { EPC } \\
\text { CFU-EC }\end{array}$ & ECFC & CEC \\
\hline Immunophenotype & $\begin{array}{c}\text { CD34+/- * } \\
\text { VEGFR2+ } \\
\text { CD133+ } \\
\text { CD31+ } \\
\text { CD146- } \\
\text { CD45+/- }\end{array}$ & $\begin{array}{c}\text { CD34+ }{ }^{*} \\
\text { VEGFR2+ } \\
\text { CD133+ } \\
\text { CD31+ } \\
\text { CD146- } \\
\text { CD45+/- }\end{array}$ & $\begin{array}{c}\mathrm{CD}_{44+}{ }^{*} \\
\text { VEGFR2+ } \\
\text { CD133+ } \\
\text { CD31+ } \\
\text { CD146- } \\
\text { CD45- }\end{array}$ & $\begin{array}{c}\text { CD34+ }{ }^{*} \\
\text { VEGFR2+ } \\
\text { CD133- } \\
\text { CD31+ } \\
\text { CD146+ } \\
\text { CD45- }\end{array}$ \\
\hline Origin & BM & BM & EC?/BM? & EC \\
\hline
\end{tabular}

\begin{tabular}{lcccc} 
Proliferative capacity & - & - & + & $-/-1+$ \\
Replating ability & - & - & + & $-/+$ \\
\hline
\end{tabular}

\begin{tabular}{lcccc} 
In vitro tube formation & $+/-$ & $+/$ & + & - \\
$\begin{array}{l}\text { In vivo de novo formation } \\
\begin{array}{l}\text { Paracrine augmentation } \\
\text { of angiogenesis }\end{array}\end{array}$ & - & - & + & - \\
\hline P & & + & $+/-$ & NA
\end{tabular}

Phagocytosis of bacteria

*In common with hematopoietic stem cells. The main differences between CEC and EPC are shown in red. EPC: endothelial progenitors cells; $\mathrm{CEC}$ : circulating endothelial cells; CAC: circulating angiogenic cells; CFU-EC: colony-forming unit-endothelial cells; ECFC: endothelial colony-forming cells;VEGFR2: vascular endothelial growth factor receptor 2; BM: bone marrow; EC: endothelial cells; NA: not applicable. cytes. ${ }^{53} \mathrm{~A}$ battery of markers is now used to identify cells of endothelial origin, including CD31, CD105, and CD141. ${ }^{54}$ Notably, the absence of CD133 may also be used to distinguish CEC from EPC. ${ }^{55}$ Currently, CEC can also be isolated by immunomagnetic selection (CD146 cells) or by flow cytometry. Notably, in 2008, Widemann et al. ${ }^{49}$ reported a hybrid assay that incorporated an algorithm combining immunomagnetic selection of $\mathrm{CD} 146^{+}$cells with flow cytometric quantification. In parallel, Terstappen's group ${ }^{56}$ developed a semi-automatic method for the detection of CEC, also using a combination of iron microbeads and monoclonal antibodies. These assays overcome the lack of standardization and the variability in CEC detection associated with the methods previously described. Moreover, the true endothelial nature of the CEC obtained using this technology was confirmed by gene expression profiling studies. ${ }^{57}$

In healthy individuals, the endothelial layer lining blood vessels is continuously being renewed at a low replication rate of $0-1 \%$ per day since normal laminar flow suppresses EC apoptosis. CEC are rare cells, with as few as $0-10 \mathrm{CEC} / \mathrm{mL}$ being observed in healthy donors. ${ }^{58}$ By contrast, elevated levels of CEC have been reported in patients with various types of diseases, including cardiovascular, ${ }^{59}$ infectious ${ }^{60}$ and immune disorrders ${ }^{61}$ diabetes, chronic kidney disease ${ }^{62}$ after hematopoietic stem cell transplantation, ${ }^{63}$ and cancer. ${ }^{64}$ Several pioneering studies have shown that raised CEC levels are also associated with specific tumor types, stage and prognosis, ${ }^{65}$ and can be used to monitor responses to chemotherapy ${ }^{66}$ In addition, CEC have been proposed as a non-invasive marker of angiogenesis. ${ }^{67}$ In contrast to EPC, which are a proposed marker of regeneration and vessel proliferation, CEC serve as a marker of endothelial damage/dysfunction and reflect a pro-thrombotic tendency ${ }^{6}{ }^{6}$ Notably, the numbers of CEC are increased in MPN patients, regardless of their driver mutational status, ${ }^{69}$ highlighting the involvement of endothelium in these chronic hematologic neoplasms.

CEC may provide a means to study mature EC that avoids laser microdissection or the limitations associated with performing the tedious and time-consuming EPC assays. However, a consensus on CEC phenotype and the origin of these cells is lacking and the possibility that EC or endothelial-like cells originate from monocytes remains.

\section{JAK2V617F-positive endothelial cells in patients with myeloproliferative neoplasms (Figure 1)}

In 2009 Sozer et al. ${ }^{8}$ reported that mature EC captured by laser microdissection from the lumen of hepatic venules harbored the JAK2V617F mutation in three MPN patients with Budd-Chiari syndrome (Figure 1, on the right). Rosti et al. further confirmed the presence of JAK2 V617F in micro-laser dissected EC from the splenic vein in MPN patients, but absence of the driver mutation in the ECFC residing in the spleen ${ }^{9}$ (Figure 1). Assayable MPN CFU-EC ${ }^{1,45,70}$ were first shown to be JAK2V617F+ while ECFC from these same patients were found to be JAK2V617F- (Figure 1). Only 3\% of the ECFC colonies analyzed by Yoder et al. ${ }^{45}$ were JAK2V617 $\mathrm{F}^{+}$. Interestingly, these mutated-ECFC were derived from the same patient, who presented with a thrombotic event and only later 
developed classic hematologic signs of polycythemia vera. Notably, increased numbers of both CFU-EC $32,34,70$ and $\mathrm{ECFC}^{71}$ have been found in the blood of patients with MPN, regardless of their mutational status. The absence of the JAK2 mutation in ECFC from MPN patients was recently confirmed by Guy and colleagues. ${ }^{13}$ Teofili et al. ${ }^{12}$ however, reported that ECFC from patients with MPN were $J A K 2 \mathrm{~V} 17 \mathrm{~F}^{+}$(Figure 1). Almost half of the MPN patients studied were reported to have MPN-like genetic abnormalities in their ECFC, including either SOCS gene hypermethylation or the presence of JAK2V617F. Notably, mutated ECFC were detected only in patients with a history of thrombotic events. ${ }^{12}$ Moreover, the presence of JAK2V617F or other evidence of clonality in ECFC was associated with JAK/STAT pathway activation and significantly greater adhesion of mononuclear cells to mutated EC than normal ECFC. ${ }^{12}$ These reports support the hypothesis that EC and HSC may derive from a common progenitor cell, the "hemangioblast", ${ }^{72}$ which results in mutated EC and myeloid cells in a subpopulation of patients with MPN. It must be said, however, that conclusive evidence unequivocally demonstrating the existence of the "hemangioblast" in vivo in higher vertebrates is lacking. Indeed, most of the published studies have been largely based on experiments that relied on the isolation, culture, and/or manipulation of cells in vitro, ${ }^{72,73}$ while various fate-mapping studies in the mouse, chick, and zebrafish have led to contradictory conclusions. ${ }^{74,75}$ Fate mapping in the zebrafish gastrula has indicated that the "hemangioblasts" are interspersed with hematopoietic and endothelial progenitors in the ventral-lateral mesoderm. ${ }^{76,77}$ In contrast, several other studies have suggested that endothelial and hematopoietic lineages are independently derived from mesodermal cells. ${ }^{78,79}$

The discovery that MPN patients may share the $J A K 2 \mathrm{~V} 617 \mathrm{~F}$ driver mutation has shed new light on this hypothesis. Moreover, some authors recently suggested that JAK2V617F, along with other myeloid malignancyassociated gene mutations, may be detected in $\mathrm{CEC}^{80}$ and HSC in patients with primary myelofibrosis. The concordance between mutations in HSC and CEC may further support the hypothesis of a common progenitor that generates these two subpopulations, but peer-reviewed studies are still required to confirm this hypothesis. Regardless of the presence of a common precursor, each of these observations supports the hypothesis that mutated EC in MPN represent a "neoplastic" vascular niche, which allows blood cell adhesion and tumor cell growth, as demonstrated using in vitro and in vivo assays.

\section{Impact of JAK2V617F endothelial cells on hematopoiesis and vascular complications in myeloproliferative neoplasms (Figure 2)}

\section{In vivo and in vitro models}

The observation that EC from some MPN patients were $J A K 2 \mathrm{~V} 17 \mathrm{~F}^{+}$stimulated the performance of additional studies exploring the possible functional consequences of $J A K 2$-mutated EC.

Etheridge et $a .^{82}$ first described the critical role of $J A K 2$ V617F-mutated EC in the development of bleeding abnormalities using murine models. They used FF1 transgenic mice to express $J A K 2 \mathrm{~V} 617 \mathrm{~F}$ in different cell lineages. In their model JAK2V617F was exclusively present in

\section{JAK2 V617F in endothelial cells}

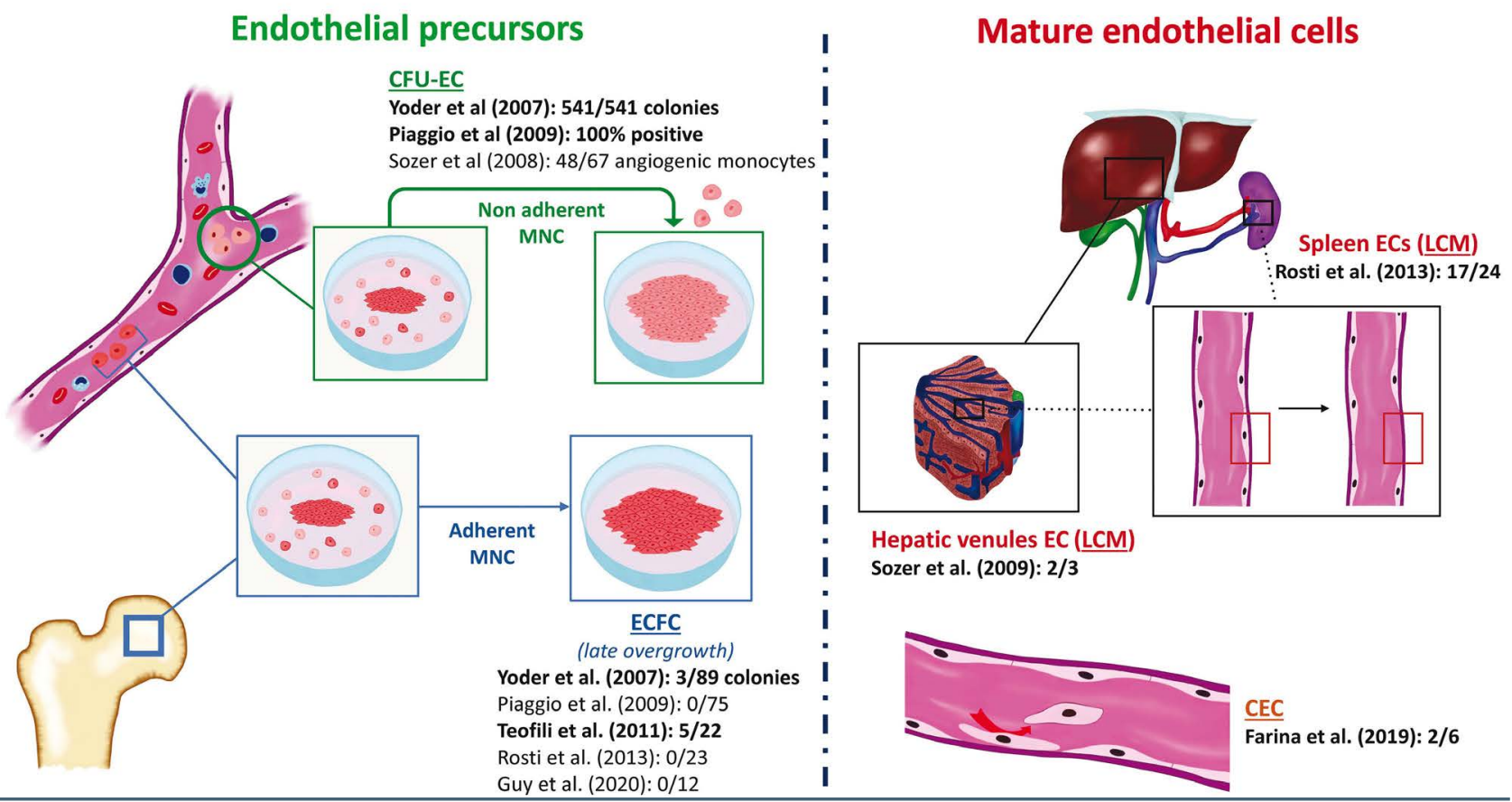

Figure 1. Evidence for JAK2V617F mutated endothelial cells in patients with myeloproliferative neoplasms. JAK2V617F has been detected in both endothelial progenitors and mature endothelial cells. Studies in which a JAK2 mutation was detected in endothelial progenitor cells or mature endothelial cells are shown in bold. Positive colonies or patients are expressed on the total number of colonies or patients analyzed. CFU-EC: colony forming unit-endothelial cells, derived from nonadherent mononuclear cell culture (see the text); MNC: mononuclear cells; EC: endothelial cells; ECFC: endothelial colony-forming cells, derived from long-term adherent MNC culture (see the text); LCM: laser-capture microdissection; CEC: circulating endothelial cells; Drawn by C. Luzzani, Medical School, University of Milan 
EC, and the mice were characterized by dysfunctional hemostasis in response to injury, resembling the bleeding diathesis observed in MPN patients. ${ }^{82}$ One of the potential mechanisms proposed by Etheridge and colleagues was related to von Willebrand factor (VWF) regulation. More recently, using both an in vitro model of human $J A K 2$ V617F-mutated EC and an in vivo model of mice with endothelial-specific JAK2V617F expression, Guy et al. ${ }^{27}$ have shown that JAK2V617F+ $\mathrm{EC}$ in the absence of similarly mutated hematopoietic cells are associated with a higher rate of thrombosis due to a pro-adhesive phenotype as a result of increased endothelial P-selectin exposure, secondary to degranulation of Weibel-Palade bodies. ${ }^{27}$ Interestingly, these mice displayed a higher propensity for thrombosis in spite of having normal blood counts and normal rates of thrombin generation. ${ }^{27}$ In contrast, their EC were characterized by increased surface expression of P-selectin and VWF, both of which are contained within Weibel-Palade bodies. Moreover, the thrombotic tendency was accentuated by the creation of a pro-inflammatory milieu due to the administration of low doses of tumor necrosis factor- $\alpha .{ }^{27}$ Furthermore, the pro-adhesive properties of the JAK2V617F-mutated EC were reversed by treatment with either a P-selectin blocking antibody or hydroxyurea. ${ }^{27}$ In addition, Poisson et al. showed an increased degree of arterial contraction in response to agents that promote vasoconstriction in mice with JAK2V617F $\mathrm{F}^{+} \mathrm{HSC}$ and EC. ${ }^{83}$

Castiglione et al. ${ }^{84}$ have reported that when JAK2V617F was expressed by both hematopoietic cells and EC in a murine model of MPN, the mice developed an MPN phe- notype and a spontaneous age-related dilated cardiomyopathy with an increased risk of sudden death as well as a pro-thrombotic and vasculopathic phenotype. In contrast, mice expressing solely JAK2V617F in blood cells did not demonstrate any evidence of cardiac dysfunction or thrombosis, suggesting that expression of the MPN driver mutation in $\mathrm{EC}$ is required for the development of the cardiovascular disease phenotype. Moreover, the authors demonstrated that the JAK2V617F ${ }^{+} \mathrm{EC}$ were associated with the development of a pro-inflammatory milieu. Finally, JAK2-mutated EC have been reported to respond to shear flow in a different manner than wild-type EC, leading to upregulation of EC adhesion molecules (platelet endothelial cell adhesion molecule and E-selectin). Guadall et al. ${ }^{28}$ have provided additional evidence that JAK2V617 ${ }^{+}$ EC possess pro-thrombotic properties. Using JAK2V617F ${ }^{+}$ and JAK2 wild-type induced pluripotent stem cells generated from an MPN patient and redirecting these cells towards the endothelial lineage, the authors observed that $J A K 2 \mathrm{~V} 17 \mathrm{~F}^{+} \mathrm{EC}$ had a greater proliferative capacity compared with wild-type EC. The numbers and fluorescence intensity of Weibel-Palade bodies as well as the expression of VWF and P-selectin were significantly greater and these effects were accompanied by greater accumulation of $\mathrm{P}$ selectin at the cell surface of $J A K 2 \mathrm{~V} 617 \mathrm{~F}^{+} \mathrm{EC}$ than wildtype EC. The transcriptomic profile of these mutated cells revealed overexpression of transcripts for genes that are involved in inflammation and cell adhesion, extracellular matrix regulation, the generation of glycoproteins, and a variety of processes that occur in venous stenosis and thrombosis.

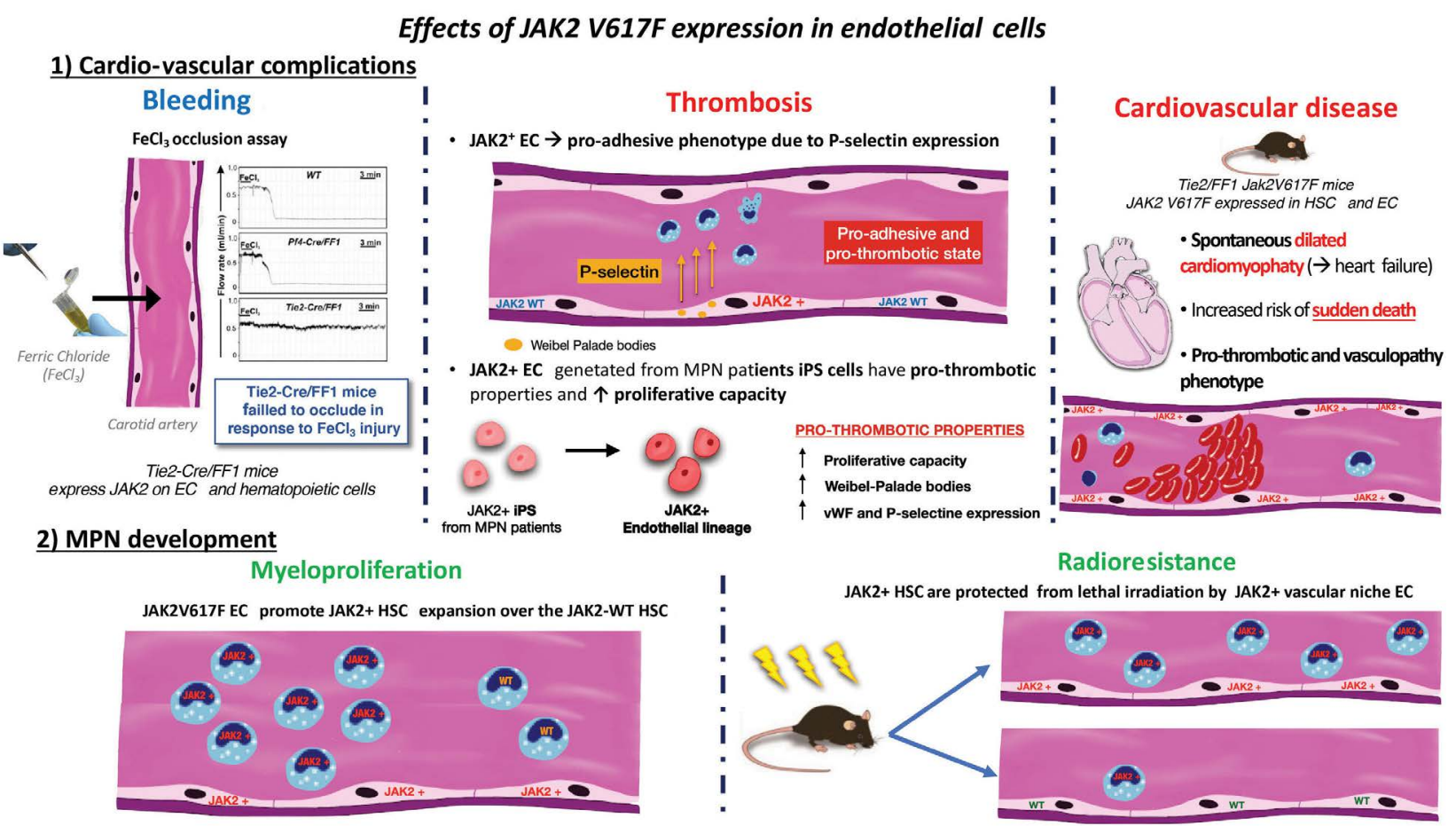

Figure 2. Effects of JAK2V617F expression in endothelial cells. The presence of the JAK2V617F mutation in endothelial cells (EC) has an impact on both (1) vascular complications and (2) the development of myeloproliferative neoplasms (MPN). Specifically, it affects bleeding ${ }^{82}$ (the carotid arteries of Tie2-Cre/FF1 mice expressing JAK2 mutations on both EC and hematopoietic stem cells (HSC) failed to occlude in response to ferric chloride, which normally induces occlusive thrombosis in murine carotid arterial); thrombosis (both in a mice model, due to enhanced P-selectin expression, ${ }^{27}$ and in an in vitro model of induced pluripotent stem cells ${ }^{28}$ ) and cardiovascular disease (mice expressing JAK2V617F had spontaneously dilated cardiomyopathy and an increased risk of sudden death ${ }^{84}$ ). Finally, JAK2-mutated EC affect MPN development, promoting JAK2 HSC expansion, ${ }^{85}$ and radioresistance. ${ }^{88} \mathrm{FeCl}_{3}$ : ferric chloride; EC: endothelial cells; MPN: myeloproliferative neoplasms; iPS: induced pluripotent stem cells; HSC: hematopoietic stem cells;. WT: wild-type. 


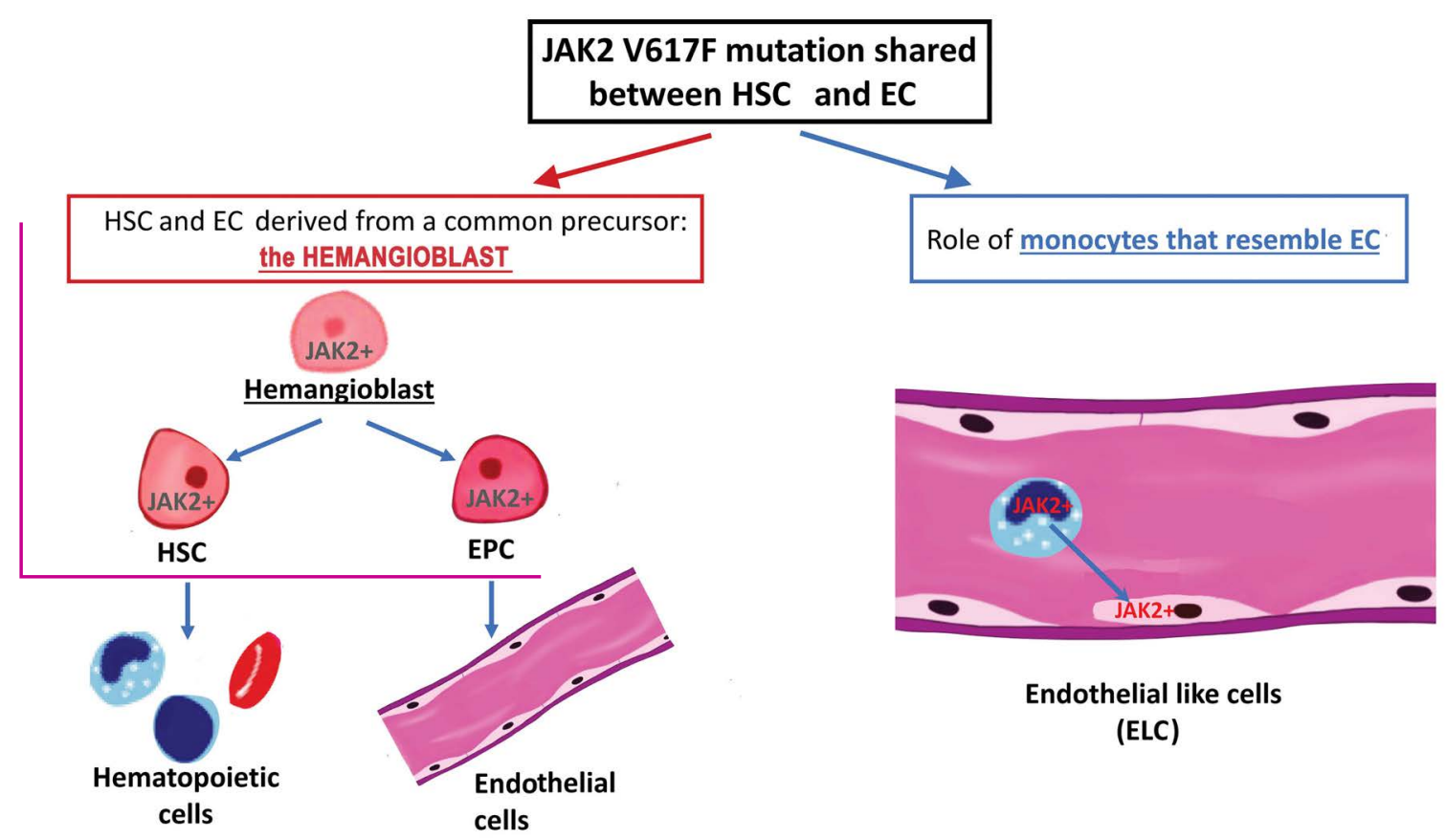

Figure 3. Possible origin of JAK2-mutated endothelial cells. The documentation of JAK2 myeloproliferative neoplasm driver mutations in myeloid cells and endothelial cells (EC) suggests that in some individuals both cell types originate from a "hemangioblast", which might serve as the cell of origin for myeloproliferative neoplasms during embryogenesis. On the other hand, JAK2-positive EC may derived from monocytes that resemble EC (endothelial-like cells) as well. EC: endothelial cells; EPC: endothelial progenitor cells; HSC: hematopoietic stem cells; ELC: endothelial-like cells.

\section{Effects of JAK2V617F-positive endothelial cells on hematopoiesis}

JAK2V617 $\mathrm{F}^{+} \mathrm{EC}$ have also been shown to contribute not only to thrombo-hemorrhagic events, but also to MPNassociated myeloproliferation..$^{85}$ JAK2V617F-bearing EC have been reported to promote the proliferation of JAK2mutated hematopoietic progenitor/stem cells over JAK2 wild-type ones in vitro. This proliferative advantage has been hypothesized to be due to activation of the thrombopoietin/MPL signaling axis. ${ }^{85}$ Subsequently, Zhan et al. provided in vivo evidence that JAK2V617F+ vascular niche cells promote JAK2V617F+ myeloid cell expansion, while inhibiting JAK2 wild-type hematopoiesis. Zhan et al. also reported that JAK2V617F+ $\mathrm{HSC}$ transplanted into wildtype recipient mice were incapable of developing an MPN phenotype in the absence of JAK2 $2617 \mathrm{~F}^{+}$vascular niche EC. Therefore, in this model MPN myeloproliferation requires JAK2V617F expression by both $\mathrm{HSC}$ and EC. ${ }^{86}$ However, there is evidence from mouse models indicating that the presence of the JAK2 mutation in HSC alone is sufficient to induce an MPN. ${ }^{87}$

In support of this role of mutated EC in MPN hematopoiesis, Lin and colleagues reported that JAK2V617 $\mathrm{F}^{+}$HSC were protected from lethal doses of irradiation by JAK2V617F+ vascular niche $\mathrm{EC}^{88}$ These authors hypothesized that the relative resistance of MPN to radiation-based conditioning regimens used prior to allogeneic stem transplantation could be due to the presence of $J A K 2 \mathrm{~V} 617 \mathrm{~F}^{+} \mathrm{EC}$ within the patient's bone marrow HSC vascular niche. ${ }^{88}$

\section{Monocytes can assume the identity of endothelial cells}

Notably, some authors have reported that monocytes isolated from MPN patients resemble endothelial-like cells, accounting for the detection of MPN driver mutations in EC and hematopoietic cells (Figure 3). Leibundgut et al. ${ }^{32}$ initially reported that $\mathrm{CD} 14^{+}$monocytes were capable of generating JAK2V617F+ EC in vitro. Subsequently, Sozer and colleagues ${ }^{10}$ showed that human CD34 cells, too, were capable of generating normal and JAK2V617F' endothelial-like cells in vivo. These reports suggest that JAK2-mutated CD34+ cells and CD14+ monocytes (both elevated in MPN) may both transform to JAK2V617F+ endothelial-like cells. These observations have led to considerable confusion, suggesting to some investigators that monocytes can transition to $\mathrm{EPC}^{46}$ and then acquire an endothelial-like phenotype. However, a more plausible hypothesis is that monocytes can serve as circulating regulators of the angiogenic response and play a crucial role in neo-angiogenesis during wound healing, tissue ischemia, and tumorigenesis by secreting pro-angiogenic factors rather than by directly participating in neo-vessel formation or endothelial turnover..$^{39,89}$

\section{Do endothelial cells and hematopoietic stem cells share a common precursor cell in patients with myeloproliferative neoplasms?}

HSC and EC are both derived from the mesodermal layer during fetal development. Some authors have speculated that they may be derived from a common precursor cell, termed a "hemangioblast". The term "hemangioblast" was initially coined by Murray in 1932,90 referring to a mass of cells derived from the primitive streak mesoderm containing both endothelial and blood cells. This term was meant to complement and contrast with the term "angioblast," which was thought to be the source of vessels and endothelium. ${ }^{91}$ During the late 
1990s, the concept of the "hemangioblast" was developed, based on observations that single mesodermal cells isolated from mice had the potential to generate both blood cells and EC. ${ }^{92}$

Interestingly, in many species HSC appear as clusters attached to the endothelium that lines the ventral wall of the abdominal aorta during embryonic development; this observation has long implicated the hemogenic endothelium as the source of developing blood cells. Indeed, when $\mathrm{EC}$ isolated from mouse embryos are grown in culture, the hemogenic endothelium possesses the potential to develop into mature blood cells. ${ }^{93}$ During development this hemogenic endothelium, gives rise to HSC/hematopoietic progenitor cells that seed the fetal liver and the adult bone marrow. ${ }^{94}$ Lineage-tracing markers in mice have identified that definitive HSC arise in the aorta-gonad-mesonephric region of embryos from hemogenic endothelium which gives rise, by asymmetric division, to resident EC and HSC that are released into the blood and then colonize the liver. ${ }^{95}$ Peault's team subsequently described the presence of definitive HSC in the aorta-gonad-mesonephric region of human embryos which were capable of colonizing adult xenografts and reported that definitive HSC were derived from hemogenic endothelium resembling those observed in mouse embryos. ${ }^{96}$ The relationship between HSC and hemogenic endothelium has been further clarified ${ }^{94}$ based on continuous single-cell imaging which indicated that freely moving cells expressing blood-specific markers (CD45, CD41, CD11b) were generated from EC expressing vascular endothelial cadherin (VE-cadherin, also known as Cdh5). ${ }^{97}$

The reports discussed above showing that the $J A K 2$ V617F driver mutation ${ }^{8,9,11,12,37,98}$ and other myeloidassociated genes mutations ${ }^{80}$ may be present in both hematopoietic cells and EC in MPN patients have reinforced the evidence supporting the existence of a common precursor cell for both EC and hematopoietic cells. In addition, some authors have recently provided evidence that JAK2V617F may be acquired in utero ${ }^{99}$ or during childhood ${ }^{100}$ by MPN patients in whom JAK2V617F was the only or the first driver mutation. This finding indicates that the acquisition of JAK2V617F in MPN patients can occur in utero and is at least chronologically consistent with involvement of the "hemangioblast" by MPN driver mutations (Figure 3). Since the period when EC are hemogenic may be very brief and occurs very early during embryogenesis, the "hemangioblast" may acquire the MPN driver mutation in only a limited group of patients. These assumptions would support the observation that not all JAK2V617F MPN patients possess mutated EC.

\section{Conclusions}

The findings summarized here indicate that mutated EC play multiple roles in the development of the clinical phenotype of MPN (Figures 2 and 3). The interaction between EC and MPN HSC creates microenvironmental niches which promote the predominance of the malignant MPN myeloid cells at the expense of the normal HSC. In addition, the documented MPN driver mutations in myeloid cells and EC suggest that in some individuals both cell types originate from a "hemangioblast" present during fetal development or which persists during adult life, and serves as the cell of origin of MPN. Further investigation using single-cell analysis of the putative MPN "hemangioblast" will be required to further confirm this hypothesis. A significant body of evidence indicates that JAK2V617F $\mathrm{F}^{+} \mathrm{EC}$ contribute to the thrombotic and bleeding tendencies of MPN patients. Additional work will also be required to assess the relative contribution of monocytes that resemble EC and mutated EPC to the prothrombotic MPN milieu. A likely scenario is that the contribution of these two types of EC to the prothrombotic tendency in MPN varies from patient to patient and may be determined in part by the vascular beds in which the thrombotic events occur.

\section{Disclosures}

No conflicts of interest to disclose.

\section{Contributions}

MF and RH conceived and wrote the manuscript. DR wrote the manuscript. All the authors approved the final version.

\section{Acknowledgments}

We acknowledge Carlo Luzzani, medical student at the University of Milan, for his help in drawing the figures provided in this review.

\section{References}

1. Spivak JL. Myeloproliferative neoplasms. N Engl J Med. 2017;376(22):2168-2181.

2. Barbui T, Finazzi G, Falanga A. Myeloproliferative neoplasms and thrombosis. Blood. 2013;122(13):2176-2184.

3. Rungiirajittranon T, Owattanapanich W, Ungprasert P, Siritanaratkul N, Ruchutrakool T. A systematic review and meta-analysis of the prevalence of thrombosis and bleeding at diagnosis of Philadelphia-negative myeloproliferative neoplasms. BMC Cancer. 2019;19(1):184

4. Kc D, Falchi L, Verstovsek S. The underappreciated risk of thrombosis and bleeding in patients with myelofibrosis: a review. Ann Hematol. 2017;96(10):1595-1604.

5. Barbui T, Carobbio A, Cervantes F, et al. Thrombosis in primary myelofibrosis: incidence and risk factors. Blood. 2010;115 (4):778-782.
6. Bar-Natan M, Hoffman R. New insights into the causes of thrombotic events in patients with myeloproliferative neoplasms raise the possibility of novel therapeutic approaches. Haematologica. 2019; 104(1):3-6.

7. Michiels C. Endothelial cell functions. J Cell Physiol. 2003;196(3):430-443.

8. Sozer S, Fiel MI, Schiano T, Xu M, Mascarenhas J, Hoffman R. The presence of JAK2V617F mutation in the liver endothelial cells of patients with Budd-Chiari syndrome. Blood. 2009;113(21): 5246-5249.

9. Rosti V, Villani L, Riboni R, et al. Spleen endothelial cells from patients with myelofibrosis harbor the JAK2V617F mutation. Blood. 2013;121(2):360-368

10. Sozer S, Ishii T, Fiel MI, et al. Human CD34+ cells are capable of generating normal and JAK2V617F positive endothelial like cells in vivo. Blood Cells Mol Dis. 2009;43(3):304-312

11. Piaggio G, Rosti V, Corselli $M$, et al. Endothelial colony-forming cells from patients with chronic myeloproliferative disorders lack the disease-specific molecular clonality marker. Blood. 2009;114 (14):31273130 .

12. Teofili L, Martini M, Iachininoto MG, et al. Endothelial progenitor cells are clonal and exhibit the JAK2V617F mutation in a subset of thrombotic patients with $\mathrm{Ph}$-negative myeloproliferative neoplasms. Blood. 2011;117(9):2700-2707.

13. Guy A, Danaee A, Paschalaki K, et al Absence of JAK2V617F mutated endothelial colony-forming cells in patients with JAK2V617F myeloproliferative neoplasms and splanchnic vein thrombosis. Hemasphere. 2020;4(3):e364.

14. Kaifie A, Kirschner M, Wolf D, et al Bleeding, thrombosis, and anticoagulation in myeloproliferative neoplasms (MPN): analysis from the German SAL-MPN-registry. J Hematol Oncol. 2016;9(1):18.

15. Guy A, Poisson J, James C. Pathogenesis of cardiovascular events in BCR-ABL1-nega- 
tive myeloproliferative neoplasms. Leukemia. 2021;35(4):935-955.

16. Hasselbalch HC, Elvers M, Schafer AI. The pathobiology of thrombosis, microvascular disease, and hemorrhage in the myeloproliferative neoplasms. Blood. 2121;137(16): 2152-2160.

17. De Stefano V, Za T, Rossi E, et al. Recurrent thrombosis in patients with polycythemia vera and essential thrombocythemia: incidence, risk factors, and effect of treatments. Haematologica. 2008;93(3):372-380.

18. Vannucchi AM, Pieri L, Guglielmelli P. JAK2 allele burden in the myeloproliferative neoplasms: Effects on phenotype, prognosis and change with treatment. Ther Adv Hematol 2011;2(1):21-32.

19. Jaiswal S, Natarajan P, Silver AJ, et al. Clonal hematopoiesis and risk of atherosclerotic cardiovascular disease. N Engl J Med. 2017;377(2):111-121.

20. Cordua S, Kjaer L, Skov V, Pallisgaard N, Hasselbalch HC, Ellervik C. Prevalence and phenotypes of JAK2 V617F and calreticulin mutations in a Danish general population. Blood. 2019;134(5):469-479.

21. Campbell PJ, MacLean C, Beer PA, et al. Correlation of blood counts with vascular complications in essential thrombocythemia: analysis of the prospective PT1 cohort. Blood. 2012;120(7):1409-1411.

22. Palandri F, Polverelli N, Catani L, Ottaviani E, Baccarani M, Vianelli N. Impact of leukocytosis on thrombotic risk and survival in 532 patients with essential thrombocythemia: a retrospective study. Ann Hematol. 2011;90(8):933-938.

23. Ronner L, Podoltsev N, Gotlib J, et al. Persistent leukocytosis in polycythemia vera is associated with disease evolution but not thrombosis. Blood. 2020;135(19):1696-1703.

24. Wolach O, Sellar RS, Martinod K, et al. Increased neutrophil extracellular trap formation promotes thrombosis in myeloproliferative neoplasms. Sci Transl Med. 2018;10(436):eaan8292.

25. Guy A, Favre S, Labrouche-Colomer S, et al. High circulating levels of MPO-DNA are associated with thrombosis in patients with MPN. Leukemia. 2019;33(10):2544-2548

26. Jensen MK, De Nully Brown P, Lund BV, Nielsen OJ, Hasselbalch HC. Increased platelet activation and abnormal membrane glycoprotein content and redistribution in myeloproliferative disorders. $\mathrm{Br} J$ Haematol. 2000;110(1):116-124

27. Guy A, Gourdou-Latyszenok V, Le Lay N, et al. Vascular endothelial cell expression of JAK2V617F is sufficient to promote a prothrombotic state due to increased P-selectin expression. Haematologica. 2019;104(1):7081.

28. Guadall A, Lesteven E, Letort G, et al. Endothelial cells harbouring the JAK2V617F mutation display pro-adherent and prothrombotic features. Thromb Haemost. 2018;118(09):1586-1599.

29. Finazzi G, Carobbio A, Thiele J, et al. Incidence and risk factors for bleeding in 1104 patients with essential thrombocythemia or prefibrotic myelofibrosis diagnosed according to the $2008 \mathrm{WHO}$ criteria. Leukemia. 2012;26(4):716-719.

30. Boveri E, Passamonti F, Rumi E, et al. Bone marrow microvessel density in chronic myeloproliferative disorders: a study of 115 patients with clinicopathological and molecular correlations. Br J Haematol. 2008;140(2): $162-168$

31. Barosi G, Rosti V, Massa M, et al. Spleen neoangiogenesis in patients with myelofi- brosis with myeloid metaplasia. $\mathrm{Br}$ Haematol. 2004;124(5):618-625.

32. Oppliger Leibundgut E, Horn MP, Brunold C, et al. Hematopoietic and endothelial progenitor cell trafficking in patients with myeloproliferative diseases. Haematologica. 2006;91(11):1465-1472.

33. Tefferi A, Pardanani A. Myeloproliferative neoplasms. JAMA Oncol. 2015;1(1):97.

34. Massa M, Rosti V, Ramajoli I, et al. Circulating CD34+, CD133+, and vascular endothelial growth factor receptor 2-positive endothelial progenitor cells in myelofibrosis with myeloid metaplasia. J Clin Oncol. 2005;23(24):5688-5695.

35. Hill JM, Zalos G, Halcox JPI, et al. Circulating endothelial progenitor cells, vascular function, and cardiovascular risk. N Engl J Med. 2003;348(7):593-600.

36. Ingram DA, Mead LE, Tanaka $\mathrm{H}$, et al. Identification of a novel hierarchy of endothelial progenitor cells using human peripheral and umbilical cord blood. Blood. 2004;104(9):2752-2760.

37. Yoder MC, Mead LE, Prater D, et al. Redefining endothelial progenitor cells via clonal analysis and hematopoietic stem/progenitor cell principals. Blood. 2007;109(5):1801-1809.

38. Murdoch C, Muthana M, Coffelt SB, Lewis CE. The role of myeloid cells in the promotion of tumour angiogenesis. Nat Rev Cancer. 2008;8(8):618-631.

39. Dudley AC, Udagawa T, Melero-Martin JM, et al. Bone marrow is a reservoir for proangiogenic myelomonocytic cells but not endothelial cells in spontaneous tumors. Blood. 2010;116(17):3367-3371.

40. Asahara T, Murohara T, Sullivan A, et al. Isolation of putative progenitor endothelial cells for angiogenesis. Science. 1997;275 (5302):964-966.

41. Urbich C, Dimmeler S. Endothelial progenitor cells. Trends Cardiovasc Med. 2004;14 (8):318-322.

42. Basile DP, Yoder MC. Circulating and tissue resident endothelial progenitor cells. J Cell Physiol. 2014;229(1):10-16.

43. Sabatier F, Camoin-Jau L, Anfosso F, Sampol J, Dignat-George F. Circulating endothelial cells, microparticles and progenitors: key players towards the definition of vascular competence. J Cell Mol Med. 2009;13(3): 454-471.

44. Vasa M, Fichtlscherer $S$, Aicher $A$, et al Number and migratory activity of circulating endothelial progenitor cells inversely correlate with risk factors for coronary artery disease. Circ Res. 2001;89(1):E1-7.

45. Yoder MC. Human endothelial progenitor cells. Cold Spring Harb Perspect Med. 2012;2(7):a006692.

46. Hirschi KK, Ingram DA, Yoder MC Assessing identity, phenotype, and fate of endothelial progenitor cells. Arterioscler Thromb Vasc Biol. 2008;28(9):1584-1595.

47. Sieveking DP, Buckle A, Celermajer DS, Ng MKC. Strikingly different angiogenic properties of endothelial progenitor cell subpopulations. Insights from a novel human angiogenesis assay. J Am Coll Cardiol. 2008;51(6):660-668

48. Melero-Martin JM, Khan ZA, Picard A, Wu $\mathrm{X}$, Paruchuri S, Bischoff J. In vivo vasculogenic potential of human blood-derived endothelial progenitor cells. Blood. 2007;109(11):4761-4768.

49. Widemann A, Sabatier F, Arnaud L, et al. CD146-based immunomagnetic enrichmen followed by multiparameter flow cytometry: a new approach to counting circulating endothelial cells. J Thromb Haemost. 2008;6 (5):869-876

50. Dignat-George F, Sampol J. Circulating endothelial cells in vascular disorders: new insights into an old concept. Eur J Haematol. 2000;65(4):215-220

51. Shantsila E, Blann AD, Lip Gyh. Circulating endothelial cells: from bench to clinical practice. J Thromb Haemost. 2008;6(5):865-868.

52. Dignat-George F, Sampol J, Lip G, Blann AD. Circulating endothelial cells: realities and promises in vascular disorders. Pathophysio Haemost Thromb. 2003;33(5-6):495-499.

53. Solovey AN, Gui L, Chang L, Enenstein J, Browne PV, Hebbel RP. Identification and functional assessment of endothelial P1H12. J Lab Clin Med. 2001;138(5):322-331.

54. Burger D, Touyz RM. Cellular biomarkers of endothelial health: microparticles, endothelial progenitor cells, and circulating endothelial cells. J Am Soc Hypertens. 2012;6(2):85-99.

55. Erdbruegger U, Haubitz M, Woywodt A. Circulating endothelial cells: a novel marker of endothelial damage. Clin Chim Acta. 2006;373(1-2):17-26.

56. Rowand JL, Martin G, Doyle GV, et al. Endothelial cells in peripheral blood of healthy subjects and patients with metastatic carcinomas. Cytometry A. 2007;71(2): 105-113.

57. Smirnov DA, Foulk BW, Doyle GV Connelly MC, Terstappen LWMM, O'Hara SM. Global gene expression profiling of circulating endothelial cells in patients with metastatic carcinomas. Cancer Res. 2006;66(6):2918-2922.

58. Boos CJ, Lip GYH, Blann AD. Circulating endothelial cells in cardiovascular disease. Am Coll Cardiol. 2006;48(8):1538-1547.

59. Werner N, Kosiol S, Schiegl T, et al Circulating endothelial progenitor cells and cardiovascular outcomes. N Engl J Med. 2005;353(10):999-1007.

60. Peters K. Molecular basis of endothelial dysfunction in sepsis. Cardiovasc Res. 2003;60(1):49-57.

61. Arica DA, Akşan B, Örem A, Altinkaynak BA, Yayli S, Sönmez M. High levels of endothelial progenitor cells and circulating endothelial cells in patients with Behçet's disease and their relationship to disease activity. An Bras Dermatol. 2019;94(3):320326.

62. Landray MJ, Wheeler DC, Lip GYH, et al. Inflammation, endothelial dysfunction, and platelet activation in patients with chronic kidney disease: the chronic renal impairment in Birmingham (CRIB) study. Am Kidney Dis. 2004;43(2):244-253

63. Almici C, Skert C, Bruno B, et al. Circulating endothelial cell count: a reliable marker of endothelial damage in patients undergoing hematopoietic stem cell transplantation. Bone Marrow Transplant. 2017;52(12):16371642

64. Bertolini F, Shaked Y, Mancuso P, Kerbel RS The multifaceted circulating endothelial cell in cancer: towards marker and target identification. Nat Rev Cancer. 2006;6(11):835845

65. DePrimo SE, Bello C. Surrogate biomarkers in evaluating response to anti-angiogenic agents: focus on sunitinib. Ann Oncol. 2007;18 Suppl 10:x11-19.

66. Fürstenberger G, von Moos R, Lucas R, et al. Circulating endothelial cells and angiogenic serum factors during neoadjuvant chemotherapy of primary breast cancer. $\mathrm{Br}$ J Cancer. 2006;94(4):524-531.

67. Beerepoot LV, Mehra N, Vermaat JSP Zonnenberg BA, Gebbink MFGB, Voest EE. 
Increased levels of viable circulating endothelial cells are an indicator of progressive disease in cancer patients. Ann Oncol. 2004;15(1):139-145.

68. Woywodt A, Scheer J, Hambach L, et al. Circulating endothelial cells as a marker of endothelial damage in allogeneic hematopoietic stem cell transplantation. Blood. 2004;103(9):3603-3605.

69. Treliński J, Wierzbowska A, Krawczyńska A, et al. Circulating endothelial cells in essential thrombocythemia and polycythemia vera: correlation with JAK2-V617F mutational status, angiogenic factors and coagulation activation markers. Int $\mathrm{J}$ Hematol. 2010;91(5):792-798.

70. Sozer S, Wang X, Zhang W, et al. Circulating angiogenic monocyte progenitor cells are reduced in JAK2V617F high allele burden myeloproliferative disorders. Blood Cells Mol Dis. 2008:41(3):284-291.

71. Rosti V, Bonetti E, Bergamaschi G, et al. High frequency of endothelial colony forming cells marks a non-active myeloproliferative neoplasm with high risk of splanchnic vein thrombosis. PLoS One. 2010;5(12): e15277.

72. Cao N, Yao Z-X. The hemangioblast:from concept to authentication. Anat Rec (Hoboken). 2011;294(4):580-588.

73. Hirschi KK. Hemogenic endothelium during development and beyond. Blood. 2012;119 (21):4823-4827.

74. Ueno H, Weissman IL. Clonal analysis of mouse development reveals a polyclonal origin for yolk sac blood islands. Dev Cell. 2006;11(4):519-533.

75. Weng W, Sukowati EW, Sheng G. On hemangioblasts in chicken. PLoS One. 2007;2(11):e1228.

76. Vogeli KM, Jin S-W, Martin GR, Stainier DYR. A common progenitor for haematopoietic and endothelial lineages in the zebrafish gastrula. Nature. 2006;443 (7109):337-339.

77. Lee JD, Treisman JE. Sightless has homology to transmembrane acyltransferases and is required to generate active Hedgehog protein. Curr Biol. 2001;11(14):1147-1152.

78. Kinder SJ, Tsang TE, Quinlan GA, Hadjantonakis AK, Nagy A, Tam PP. The orderly allocation of mesodermal cells to the extraembryonic structures and the anteroposterior axis during gastrulation of the mouse embryo. Development. 1999;126 (21):4691-4701.
79. Furuta C, Ema H, Takayanagi S-I, et al. Discordant developmental waves of angioblasts and hemangioblasts in the early gastrulating mouse embryo. Development. 2006;133(14):2771-2779.

80. Farina M, Bernardi S, Polverelli N, et al. Comparative somatic mutational profiling of CD34+ hematopoietic precursors (HSC) and circulating endothelial cells (CEC) in patients with primary myelofibrosis (PMF). Blood. 2019;134(Suppl_1):1684.

81. Teofili L, Larocca LM. Blood and endothelial cells: together through thick and thin. Blood. 2013;121(2):248-249.

82. Etheridge SL, Roh ME, Cosgrove ME, et al. JAK2V617F-positive endothelial cells contribute to clotting abnormalities in myeloproliferative neoplasms. Proc Natl Acad Sci U S A. 2014;111(6):2295-2300.

83. Poisson J, Tanguy $\mathrm{M}$, Davy $\mathrm{H}$, et al. Erythrocyte-derived microvesicles induce arterial spasms in JAK2V617F myeloproliferative neoplasm. J Clin Invest. 2020;130 (5):2630-2643.

84. Castiglione M, Jiang YP, Mazzeo C, et al. Endothelial JAK2V617F mutation leads to thrombosis, vasculopathy, and cardiomyopathy in a murine model of myeloproliferative neoplasm. J Thromb Haemost. 2020;18(12):3359-3370.

85. Lin CHS, Kaushansky K, Zhan $\mathrm{H}$. JAK2V617F-mutant vascular niche contributes to JAK2V617F clonal expansion in myeloproliferative neoplasms. Blood Cells Mol Dis. 2016;62:42-48.

86. Zhan H, Kaushansky K. Functional interdependence of hematopoietic stem cells and their niche in oncogene promotion of myeloproliferative neoplasms: the 159th biomedical version of "it takes two to tango." Exp Hematol. 2019;70:24-30.

87. Lundberg P, Karow A, Nienhold R, et al. Clonal evolution and clinical correlates of somatic mutations in myeloproliferative neoplasms. Blood. 2014;123(14):2220-2228.

88. Lin CHS, Zhang Y, Kaushansky K, Zhan H. JAK2V617F-bearing vascular niche enhances malignant hematopoietic regeneration following radiation injury. Haematologica. 2018;103(7):1160-1168.

89. De Palma M, Venneri MA, Galli R, et al. Tie2 identifies a hematopoietic lineage of proangiogenic monocytes required for tumor vessel formation and a mesenchymal population of pericyte progenitors. Cancer Cell.
2005;8(3):211-226.

90. Murray PDF. The development in vitro of the blood of the early chick embryo. Proc $\mathrm{R}$ Soc Lond B. 1932;111(773):497-521.

91. Sabin FR. Preliminary note on the differentiation of angioblasts and the method by which they produce blood-vessels, bloodplasma and red blood-ells as seen in the living chick. J Hematother Stem Cell Res. 2002;11(1):5-7.

92. Choi K, Kennedy M, Kazarov A Papadimitriou JC, Keller G. A common precursor for hematopoietic and endothelia cells. Development. 1998;125(4):725-732.

93. Nishikawa S-I, Nishikawa S, Kawamoto H et al. In vitro generation of lymphohematopoietic cells from endothelial cells purified from murine embryos. Immunity. 1998;8(6):761-769.

94. Lancrin C, Sroczynska P, Stephenson C, Allen T, Kouskoff V, Lacaud G. The haemangioblast generates haematopoietic cells through a haemogenic endothelium stage. Nature. 2009;457(7231):892-895.

95. Dzierzak E, Bigas A. Blood development: hematopoietic stem cell dependence and independence. Cell Stem Cell. 2018;22(5): 639-651.

96. Zambidis ET, Peault B, Park TS, Bunz F, Civin CI. Hematopoietic differentiation of human embryonic stem cells progresses through sequential hematoendothelial primitive, and definitive stages resembling human yolk sac development. Blood. 2005;106(3):860-870.

97. Eilken HM, Nishikawa S-I, Schroeder T. Continuous single-cell imaging of blood generation from haemogenic endothelium. Nature. 2009;457(7231):896-900.

98. Helman R, Pereira W de O, Marti LC, et al Granulocyte whole exome sequencing and endothelial JAK2V617F in patients with JAK2V617F positive Budd-Chiari syndrome without myeloproliferative neoplasm. Br J Haematol. 2018;180(3):443-445.

99. Williams $\mathrm{N}$, Lee J, Moore $\mathrm{L}$, et al Phylogenetic reconstruction of myeloproliferative neoplasm reveals very early origins and lifelong evolution. bioRxiv 2020;2020: 374710.

100. Van Egeren D, Escabi J, Nguyen M, et al. Reconstructing the lineage histories and differentiation trajectories of individual cancer cells in myeloproliferative neoplasms. Cell Stem Cell. 2021;28(3):514-523. 